\title{
STOSUNKI DYPLOMATYCZNE POLSKI I ZSRR 1933-1934
}

\section{Dyplomacja polska wobec radzieckiego projektu deklaracji bałtyckiej z 1933 r.}

Podpisanie 25 lipca 1932 r. polsko-radzieckiego paktu o nieagresji ${ }^{1}$ otworzyło nie tylko nowy etap w stosunkach dwustronnych obu państw, ale również miało poważny wpływ na stosunki Polski z Francją, Niemcami, Rumunią i krajami bałtyckimi. Polsko-radziecki pakt o nieagresji mógł stać się punktem wyjścia do bliższej współpracy obu państw. Okres kilkunastu miesięcy od zawarcia paktu do końca 1933 r. cechuje wyjątkowy dla stosunków polsko-radzieckich okresu międzywojennego charakter zbliżenia².

Wzajemne krótkotrwałe zbliżenie po podpisaniu paktu spowodowane było tym, że zarówno Polska jak i ZSRR znalazły się w izolacji politycznej. Trudna sytuacja Polski na arenie międzynarodowej wiosną 1933 r. spowodowana była rosnącym zagrożeniem ze strony Niemiec, rozluźnieniem więzów sojuszniczych z Francją i Rumunią oraz widmem „paktu czterech”, realizacja którego mogła stanowić dla Polski groźbę rewizji jej granic. Stosunki radziecko-niemieckie od początku 1933 r. ulegały stałemu pogorszeniu, na co niewątpliwy wpływ miały

${ }^{1}$ Tekst paktu zob.: „Dziennik Ustaw RP”, 24 XII 1932 r., nr 115, poz. 95 1, też: Dokumenty i materialy do histórii stosunków polsko-radzieckich (dalej: DIM), t. V, Warszawa 1966, s. 592-594; Zagadnieniem polsko-radzieckiego paktu o nieagresjizajmowali się: St. Zabiełlo (ps. S. Jaworznicki), Polsko-radziecki pakt o nieagresji z 1932 r., „Sprawy Międzynarodowe”, (dalej - „SM”), 1952, nr 5; St. Łopatniuk, Polsko-radzieckie rokowania $w$ sprawie zawarcia paktu o nieagresji, „Z dziejów stosunków polsko-radzieckich. Studia i materiały” (dalej: „Z dziejów...”), 1965, t. I; tamże, Polsko-radziecki pakt o nieagresji, [w:] Stosunki polsko-radzieckie 1917-1939, Warszawa 1973; W. Daszkiewicz, Polityka zagraniczna ZSRR (1929-1933), „SM”, 1963, nr 3; tamże, Z dziejów stosunków polsko-radzieckich 1932-1934 r., „SM”, 1967, nr 2 i 3; M. Leczyk, Podpisanie paktu o nieagresji między Polskq a ZSRR w 1932 r., „Dzieje Najnowsze", 1973, nr 2; Polityka II Rzeczypospolitej wobec ZSRR w latach 1925-1934, Warszawa 1976 oraz A. Skrzypek, Polsko-radziecki pakt o nieagresji z 1932 r., „Z dziejów...”, 1976, t. XIII; zob. również 18 dokumentów dotyczących rokowań o pakt o nieagresji opublikowanych przezSt. Łopatniuka, „Z dziejów...”, 1969, t. V.

${ }^{2}$ Zob. S. Zabiełlo, Rok odwilzy, [w:] W kręgu historii, Warszawa .1970; M. Leczyk, Polityka II Rzeczypospolitej..., s. 303-329; S. Gregorowicz, Polsko-radzieckie stosunki polityczne w latach 1932-1935, Warszawa 1982. 
antykomunistyczne wystąpienia przedstawicieli III Rzeszy na arenie międzynarodowej ${ }^{3}$. Wiązało się z tym przechodzenie Związku Radzieckiego od polityki rapallskiej na pozycje prowersalskie, czyli asekurowanie się przed niebezpieczeństwem ze strony Niemiec hitlerowskich. Naprężona sytuacja na Dalekim Wschodzie w stosunkach z Japonią oraz negaty wny stosunek do „paktu czterech” stwarzał ZSRR możliwość współdziałania z Polską przeciw próbie dyrektoriatu czterech mocarstw ${ }^{5}$ - tj. Wielkiej Brytanii, Francji, Niemiec i Włoch.

Istotnym momentem zbliżenia polsko-radzieckiego było podpisanie 3 lipca regionalnej Konwencji o definicji napastnika przez ZSRR, Polskę, Rumunię, Turcję, Persję, Afganistan, Łotwę i Estonię, a 22 lipca również przez Finlandię

Ostatnie miesiące 1933 r. przyniosły jednak w stosunkach między Moskwą i Warszawą wzrost nieufności. Powodem było rysujące się zbliżenie polsko-niemieckie, czego wyrazem miała się stać deklaracja o niestosowaniu siły. W Moskwie zbliżenie Polski do Niemiec, które po opuszczeniu 14 X 1933 r. Ligi Narodów i genewskiej konferencji rozbrojeniowej znalazły się w izolacji politycznej”, wywołało niepokój. Komunikat Agencji Wolffa z 15 listopada o rozmowie kanclerza Rzeszy Adolfa Hitlera z posłem polskim w Berlinie Józefem Lipskim, zawierający zapowiedź podpisania polsko-niemieckiej deklaracji o nieagresji, stał się powodem interpelacji zastępcy ludowego komisarza spraw zagranicznych Borisa Stomoniakowa w rozmowie z polskim posłem w Moskwie Juliuszem Łukasiewiczem. Polski dyplomata potwierdził, że rozmowy polsko-niemieckie zmierzają do podpisania deklaracji o nieagresji ${ }^{\text {. }}$.

Nie wydaje się trafną tezą A. Skrzypka, że ocena radzieckiego komunikatu Lipski-Hitler była spokojna"; była ona być może spokojna w formie, ale nie w treści. Następstwem bowiem rozmowy Łukasiewicza ze Stomoniakowem było przeprowadzenie przez posła ZSRR w Polsce Władimira Antonowa-Owsiejenki serii rozmów z ministrem spraw zagranicznych Józefem Beckiem i czołowymi publicystami obozu rządowego: Bogusławem Miedzińskim, Wojciechem

${ }^{3} \mathrm{Na}$ konferencji ekonomicznej w Londynie (12-17 VI 1933 r.) minister wyżywienia i rolnictwa Niemiec Alfred Hugenberg wręczył przewodniczącemu Komisji Ekonomicznej Konferencji memorandum, w którym postulował oddanie do dyspozycji „narodu bez przestrzeni życiowej” bliżej nieokreślonych terytoriów. Memorandum A. Hugenberga sugerowalo, że chodzi tu o tereny ZSRR. Tekst memorandum: Documents on German Foreign Policy 1918-1945, (dalej DGFP), S.C., vol I, The Third Reich, Firs Phase, January 30-October 14, 1933, London 1957, dok. 312, s. 562-567; Zbiór dokumentów. Dodatek do „Polityki Narodów”, 1933, z. 7, s. 114-115; Reakcja radziecka zob.: Dokumienty wnieszniej politiki SSSR (dalej: DWP), t. XVI, Moskwa 1970, dok. 189 i 190, s. 359-361.

${ }^{4}$ M. Wojciechowski, Stosunki polsko-niemieckie 1933-1938, Poznań 1965, s. 65.

${ }^{5}$ H. Ross, Polen und Europa. Studien sur polnischen Aussen politik 1931-1939, Tübingen 1957, s. 95; szerzej na ten temat zob.: B. Rakowski, Polsko-radzieckie aspekty paktu czterech mocarstw, [w:] „Z dziejów...", t. X, s. 110.

'J. Beck, Przemówienia, deklaracje, uywiady 1931-1939, Warszawa 1939, s. 71; zob. też: A. Skrzypek, Strategia pokoju. Radziecka polityka zbiorowego bezpieczeństwa w Europie 1932-1939, Warszawa 1979, s. 74-75; W. Materski, Tarcza Europy. Stosunki polsko-sowieckie 1918-1939, Warszawa 1994, s. $265-266$.

${ }^{7}$ A. Freitag-Loringhoven, Aussenpolitik 1933-1940, Berlin 1941, s. 29; zob. też: B. Rakowski, Dyplomacja hitlerowska wobec Genewskiej Konferencji Rozbrojeniowej, [w:] Zeszyty Naukowe Uniwersytetu Łódzkiego, Nauki Humanistyczno-Spoleczne, Seria I, zeszyt 58, Łódź 1968, s. 147-160.

${ }^{8}$ DIM, t. VI, dok. 70, s. 111.

${ }^{y}$ A. Skrzypek, op. cit., s. 36. 
Stpiczyńskim i Ignacym Matuszewskim ${ }^{10}$. Przebieg rozmów został już szeroko zanalizowany przez Mariana Leczyka ${ }^{11}$.

Poseł radziecki na podstawie przeprowadzonych rozmów przesłał 27 listopada do Ludowego Komisariatu Spraw Zagranicznych (dalej LKSZ) interesującą ocenę polskiej polityki zagranicznej. Doszedł do wniosku, że dyplomaci polscy uważają, że nie istnieje żaden wspólny front wymierzony przeciw rewizjonistycznej polityce Niemiec. Francja, Wielka Brytania, Włochy i państwa Małej Entanty gotowe są do rozwiązania problemów europejskich kosztem Polski. Tezę tą potwierdzało podpisanie przez Francję, dodajmy, że również przez Anglię, „paktu czterech"(który nie wszedł jednak w życie) i rokowania w sprawach rozbrojeniowych. Sytuacja taka mogła doprowadzić do izolacji Polski na arenie międzynarodowej. Zbliżenie do ZSRR, któremu towarzyszyła faktyczna likwidacja polityki Rapalla, poprawiało sytuację Polski. Według Antonowa-Owsiejenki Polska nie mogąc zabezpieczyć się przed Rzeszą poprzez wojnę prewencyjną, musiała dążyć do złagodzenia stosunków polsko-niemieckich. Poseł radziecki zaznaczył, że Polska stara się by problemy, którymi jest zainteresowana, były rozpatrywane przy jej udziale ${ }^{12}$.

W. Antonow-Owsiejenko trafnie określił jedną z naczelnych zasad polskiej polityki zagranicznej, według której Polska przeciwstawiała się każdej koncepcji politycznej, w której mocarstwa zachodnie mogłyby rozpatrywać sprawy państw mniejszych bez ich udziału. Sytuacja taka bowiem mogłaby sprzyjać tendencjom rewizjonistycznym Niemiec w kwestii granicy polsko-niemieckiej ${ }^{13}$.

LKSZ uważał, że tempo zbliżenia na linii Warszawa - Moskwa jest zbyt powolne, a dotychczasowe formy współpracy niewystarczające ${ }^{14}$. Obawy radzieckie przedstawił 23 XI $1933 \mathrm{r}$. W. Antonow-Owsiejenko w rozmowie z redaktorem naczelnym „Gazety Polskiej” J. Matuszewskim $^{15}$. Wskazując, że o rozmowach polsko-niemieckich rząd radziecki nie był poinformowany przez Polskę, sugerował, że jego rząd musi odnieść wrażenie, że aktualny stan stosunków polsko-radzieckich, tj. zbliżenie na linii Warszawa - Moskwa, wykorzystywane jest przez dyplomację polską do wywarcia presji na Berlin.

$\mathrm{Na}$ Wierzbowej trafnie oceniono stosunek ZSRR do Niemiec, że „polityce sowieckiej będzie zależało na tym, aby odprężenie, które daje się zauważyć ostatnio w stosunkach pomiędzy hitlerowskimi Niemcami, a ich sąsiadami i mocarstwami zachodnioeuropejskimi, nie poszło zbyt daleko i aby tempo odprężenia nie było zbyt szybkie. W interesie ZSRR leży niewątpliwie możliwie długotrwała i kompletna izolacja Niemiec hitlerowskich na terenie międzynarodowym"16.

Punkt ciężzości polityki polskiej został ostatecznie w październiku 1933 r. przesunięty przez J. Piłsudskiego na Niemcy ${ }^{17}$. Poprawne stosunki polsko-radzieckie były czynnikiem presji na Niemcy w celu sfinalizowania deklaracji o nieagresji. Polska starała się o podtrzymywanie w Mo-

${ }^{10}$ DIM, t. VI, dok. 74, s. 115-120; tamże, dok. 75, s. 121-126.

${ }^{13}$ Zob. M. Leczyk, Polityka II Rzeczypospolitej..., s. 329-350 oraz S. Gregorowicz, op. cit., s. 195.

12 DIM, t. VI, dok. 75, s. 121-122.

${ }^{13}$ M.J. Zacharias, Problem niemiecki w stosunkach polsko-radzieckich (jesień 1933 - wiosna 1934), [w:] „Z dziejów...” 1977, t. XVI, s. 71.

${ }^{14}$ J.P. Iwaszin, Oczerki istorii wnieszniej politiki SSSR, Moskwa 1958, s. 228.

${ }^{15}$ DIM, t. VI, dok. 74, s. 119.

${ }^{16}$ DIM, t. VI, dok. 82, s. 135.

${ }^{17}$ Zob. M. Wojciechowski, op. cit., s. 114-118. 
skwie wrażenia gotowości do pogłębienia współpracy, nie wychodząc jednak z konkretnymi projektami. Świadczy o tym rozmowa polskiego ministra z posłem radzieckim z 23 listopada. $\mathrm{Na}$ początku zauważył on, że „wszystkie instytucje genewskie się załamały, załamała się konferencja rozbrojeniowa. Pozostają próby rozwiązania stojących problemów poza Genewą. Kiedy my występujemy sami, mówi się «mały kraj», kiedy my występujemy sami «daleki kraj», jeżeli jednak wystąpimy razem, to te określenia od razu odpadną"18. J. Beck poruszył problem wspólnej akcji w państwach bałtyckich, które określił „miękkim punktem” Europy.

Wypowiedź Becka zasługuje na szczególną uwagę, gdyż sugerował on, w drodze blizej nieokreślonych kroków ekonomicznych i politycznych, wzmocnienie państw bałtyckich, narażonych jego zdaniem na silną penetrację Niemiec. Na konkretne pytanie posła radzieckiego, czy ma to oznaczać propozycję wspólnej polityki na tym terenie, Beck odpowiedział wymijająco, że’należy uważnie przestudiować problem „miękkiego punktu” i zakończył rozmowę stwierdzeniem: „o tym trzeba będzie jeszcze rozmawiać"19.

Wypowiedź J. Becka, mimo braku konkretnych propozycji zawierała jednak sugestię pewnej współpracy obu państw, która mogłaby stanowić platformę dalszego zbliżenia. Na problemy te zwracał uwagę w początkach grudnia J. Łukasiewicz. Według posła polskiego, w Moskwie zagadnienia międzynarodowe, wykraczające poza zakres stosunków polsko-radzieckich, są jedynym terenem, na którym mógłby postępować proces zbliżenia obu państw, oraz „mogłyby być definitywnie zatarte ślady wątpliwości i żalów powstałych po stronie sowieckiej w związku z deklaracją Lipski-Hitler"20.

W rzeczywistości jednak współpraca polityczna Polski i ZSRR na gruncie stosunków międzynarodowych nie była już możliwa wobec odmiennych założeń politycznych.

ZSRR wystąpił jednak z inicjatywą wspólnej akcji dyplomatycznej obu państw. Biorąc za punkt wyjścia oświadczenie Becka w rozmowie z 23 listopada z Antonowem-Owsiejenką, Maksym Litwinow 13 grudnia wysunął wobec Łukasiewicza projekt wspólnej deklaracji polsko-radzieckiej w sprawach bałtyckich. Brzmiał on następująco: „ZSRR i Polska występują ze wspólną deklaracją o ich kategorycznym zdecydowaniu ochronienia i bronienia pokoju we wschodniej Europie. Oba państwa nadmieniają, że koniecznym warunkiem tego pokoju jest nienaruszalność i pełna gospodarcza i polityczna niezawisłość nowych państw oraz, że ta niezawisłość stanowi przedmiot troski obu państw. Na wypadek zagrożenia niezawisłości państw bałtyckich ZSRR i Polska zobowiązują się nawiązać natychmiast kontakt między sobą i omówić powstałą sytu-

${ }^{18}$ DIM, t. VI, dok. 81, s. 132.

${ }^{19}$ Odpowiedni fragment rozmowy brzmi: „na mapie Europy jest «miękki punkt» - to są państwa bałtyckie. Tu i dawne, ułożono mocne państwa i nowe, jeszcze w fermencie. $Z$ jednej strony Szwecja, gdzie niemieckie wpływy nie tak dawno były jeszcze bardzo silne. (Ja dodałem: «i angielskie - przez dwór i admiralicję» - Beck zgodzil się); z drugiej Finlandia szczególnie germanofilska, Łotwa - z wzrastającym niemieckim wpływem, Estonia, gdzie one są najsłabsze (szczegółowo mówi o naszej omyłkowej innej ocenie) i Litwa, która stoi na rozdrożu. «My jednakowo jesteśmy zainteresowani w umacnianiu tego miękkiego punktu i należałoby znaleźć szereg ekonomicznych i politycznych sposobów do jego umocnienia». Ja, prosto zapytałem: «to znaczy, wy proponujecie nam prowadzenie wspólnej polityki w państwach nadbałtyckich». Beck odpowiedział dyplomatycznie: «Należy z uwagą opracować to zagadnienie - ja osobiście jestem nim teraz zajęty - dla umocnienia tego kierunku. Tu cały kompleks zagadnień, które należy opracować. O tym jeszcze warto pomówić». Tamże, s. 132-133.

20 DIM, t. VI, dok. 82, s. 134-136. 
ację"21. M. Litwinow dodał, że deklaracja nie oznaczałaby sojuszu wojskowego, zmuszałaby jednak do zastanowienia się tych, którzy chcieliby naruszyć pokój nad Bałtykiem²2.

J. Łukasiewicz uznał, że wysunięcie projektu deklaracji uwarunkowane było trzema okolicznościami: 1. chęcią Moskwy do posunięcia naprzód zbliżenia politycznego z Polską i zabezpieczenia się przed ewentualną zmianą kierunku naszej polityki zagranicznej, 2. zaniepokojeniem o los państw bałtyckich zarówno w związku z możliwymi tendencjami polityki Hitlera, jak i tzw. faszyzacją wewnętrzną Łotwy i Estonii, 3. chęcią skompromitowania Polski w stosunku do Hitlera i utrudnienia, albo uniemożliwienia, rozwijania nadal odprężenia zainaugurowanego przez deklarację Lipski-Hitler ${ }^{23}$.

Do tych argumentów skłania się również M. Leczyk w swej książce ${ }^{24}$.

Zasadniczym jednak celem wystąpienia M. Litwinowa, było „skrystalizowanie przez ogłoszenie deklaracji bałtyckiej czegoś w rodzaju sojuszu politycznego polsko-sowieckiego" ${ }^{2}$. W planach radzieckich deklaracja bałtycka była fragmentem akcji zmierzającej do stworzenia antyniemieckiego frontu radziecko-polsko-francuskiego i była ściśle związana $\mathrm{z}$ negocjowanym paktem o wzajemnej pomocy między Francją a ZSRR ${ }^{26}$. Ostatnie tygodnie 1933 r. stanowiły bowiem w stosunkach francusko-radzieckich przełomowy okres, w którym wyłoniła się koncepcja paktu zbiorowego bezpieczeństwa - tzw. Paktu Wschodniego.

Koncepcja M. Litwinowa oparta była na wynikach rozmów, jakie przeprowadził we wrześniu 1933 r. nieoficjalnie w Moskwie Edouard Herriot oraz na francusko-radzieckich rozmowach prowadzonych w październiku-listopadzie 1933 r. w Paryżu. Francja odrzucając dwustronny sojusz z ZSRR wysunęła koncepcję paktu zbiorowego bezpieczeństwa - tj. Paktu Wschodniego ${ }^{27}$.

Plan francuski wychodził więc znacznie poza ramy dwustronnej deklaracji przedstawionej w projekcie M. Litwinowa. W tej sytuacji zrozumiałym jest, że wobec niewykrystalizowania się ostatecznej koncepcji paktu wzajemnego bezpieczeństwa i niejasnego dla ZSRR zbliżenia Polski do Niemiec, deklaracja bałtycka spełniała także inne funkcje.

ZSRR poprzez wysunięcie projektu deklaracji, według której Polska stawała się jednym z gwarantów niepodległości państw bałtyckich, odstępował od swojej tradycyjnej polityki zwalczania wpływów polskich na tym terenie. Projekt Litwinowa był również próbą sondażu aktualnego stanu stosunków polsko-niemieckich; deklaracja bałtycka, w wypadku jej przyjęcia, zapewne skomplikowałaby te stosunki, o co Moskwie właśnie chodziło ${ }^{28}$. Z drugiej strony de-

${ }^{21}$ Telegr. szyfr. Nr GMS 4050 J. Łukasiewicza z 14 XII 1933 r., ANN, MSZ, P III, t. 6764, k. l; zob. też: DIM, t. VI, dok. 89, s. 158; K. Lapter, Problem baltycki w stosunkach Polski z Niemcami i Zwiqzkiem Radzieckim w okresie międzywojennym, [w:] „Studia z Najnowszych Dziejów Powszechnych”, 1963, t. 4, s. 14.

22 Tamże.

${ }^{23}$ List J. Łukasiewicza do J. Becka z 15 XII 1933 r., ANN, MSZ, P III, t. 6764, k. 81-90.

${ }^{24}$ M. Leczyk, Polityka II Rzeczypospolitej..., s. 343.

${ }^{25}$ Rap. J. Łukasiewicza Nr 49/Sow/12/ś.tjn z 20 II 1934 r., AAN, MSZ, P III, t. 6764.

26 Tamże.

27 W. Daszkiewicz, Dążenia ZSRR do stworzenia ogólnoeuropejskiego systemu bezpieczeństwa zbiorowego w latach 1933-1934, „Przegląd Zachodni”, 1964, nr 2, s. 205-208; szerzej o tym w rozdziale III.

${ }^{28} \mathrm{M}$. Wojciechowski trafnie zauważa, że „niepodległość krajów bałtyckich była w warunkach ówczesnego układu sił politycznych w Europie istotnym zabezpieczeniem północnego krańca zachodniej granicy ZSRR. Współdziałanie Polski i Niemiec mogło zaś stanowić zagrożenie dla suwerenności republik bałtyckich. Wystarczy przypomnieć kierujące się w stronę Litwy pomysły kompensacyjne Hitlera"; M. Wojciechowski, op. cit., s. 100; por. list J. Łukasiewicza z 15 XII 1933 r. do J. Becka, ANN, MSZ, P III, t. 6764 , s. 81-90. 
klaracja bałtycka, według rachub dyplomacji radzieckiej, mogła stać się punktem wyjścia do ściślejszej współpracy Polski z ZSRR w tym regionie ${ }^{29}$.

W świetle zachowanych dokumentów słuszną wydaje się teza, że dyplomacja polska traktowała w ścisłej zależności projekt deklaracji bałtyckiej z rokowaniami o polsko-niemieckiej deklaracji o nieagresji ${ }^{30}$. Była to ze strony polskiej próba nacisku na Niemcy w celu sfinalizowania tej deklaracji.

Beck wobec propozycji radzieckiej nie mógł posunąć się zbyt daleko. Jej sfinalizowanie w formie wysuniętej przez M. Litwinowa (a więc zawierającej wyraźne ostrze antyniemieckie) oznaczałoby dla Polski przekreślenie jej planów poprawy stosunków z Niemcami, a z drugiej strony położyłoby kres jej samodzielnej polityki w państwach bałtyckich, a także utrudniłoby w przyszłości rozwiązanie zagadnienia litewskiego. Dalsze zbliżenie ZSRR, po podpisaniu paktu o nieagresji, nie było według Becka potrzebne ${ }^{31}$, byłoby bowiem sprzeczne z przyjętą polityką równych odległości do Moskwy i do Berlina.

Natomiast Beck starał się wywrzeć wrażenie na Moskwie, że sprawę deklaracji bałtyckiej gotów jest sfinalizować, zwłaszcza że znana była dyplomacji polskiej postawa strony radzieckiej obserwującej ostatnie posunięcia Polski „w stosunku do Niemiec z nieufnością większą, niż by to oficjalnie chciała dać do poznania" ${ }^{32}$. Łukasiewicz sugerował jednak Beckowi, że podpisanie deklaracji bałtyckiej oznaczałoby pogorszenie stosunków z Niemcami, a „z drugiej strony w dzisiejszym stanie stosunków naszych z Moskwą, kiedy nieufność jest jeszcze ciągle rozbudowana i oddziałuje dość silnie, byłoby moim zdaniem, niewskazane stwarzać nowe poważne nieporozumienie lub narażać Litwinowa na zupełny zawód”33, przez odrzucenie deklaracji bałtyckiej. Była to zatem rada: i tak źle i tak niedobrze.

Równocześnie Łukasiewicz pisał, że nowo mianowany jesienią 1933 r. ambasador III Rzeszy w ZSRR Rudolf Nadolny wkrótce rozpocznie działalność w celu poprawy stosunków radziecko-niemieckich. Polski poseł informował, że w interesie ZSRR leży izolacja Niemiec na terenie międzynarodowym. "Jeśli jednak izolacja ta nie da się w dostatecznym stopniu utrzymać - pisał Łukasiewicz, jest moim zdaniem, prawdopodobne, że i rząd sowiecki pójdzie na znaczne złagodzenie stosunków z Niemcami”34.

W tej sytuacji Beck wyraził zgodę na podjęcie rozmów z Moskwą w sprawie deklaracji bałtyckiej, ubezpieczając się w ten sposób przed możliwością poprawy stosunków radziecko-niemieckich, w okresie gdy polsko-niemiecka deklaracja o nieagresji była przedmiotem rokowań.

Zaznaczyć należy, że podjęcie rozmów w sprawie deklaracji bałtyckiej miało również na celu zapobieżenie ewentualnej akcji niemieckiej w krajach bałtyckich ${ }^{35}$. Polska bowiem dążyła do wzmocnienia w tym rejonie swego prestiżu i pozycji w rozgrywce z III Rzeszą i ZSRR. Z drugiej strony na decyzję Polski podjęcia propozycji Litwinowa pewien wpływ mogła mieć

${ }^{29}$ Rap. Nr 49/Sow/12/ś.tjn./ J. Łukasiewicza z 20 II 1934 r., ANN, ASZ, P III, t. 6764, k. 175-181.

${ }^{30} \mathrm{~K}$. Lapter, op. cit., s. 14.

${ }^{31}$ P. Starzeński, Trzy lata z Beckiem, Londyn 1972, s. 83.

${ }^{32}$ Notatka z rozmowy posła RP w Helsinkach Fr. Charwata z posłem ZSRR B. Steinem z 23 XII 1933 r., ANN, MSZ, P III, t. 6751, k. 7.

${ }^{33}$ List J. Łukasiewicza do J. Becka z 15 XII 1933 r., ANN, MSZ, P III, t. 6764, k. 81-90.

${ }^{34}$ DIM, t. VI, dok. 82, s. 134-135.

${ }^{35}$ Zob. bliżej K. Lapter, op. cit., s. 11-12; M.J. Zacharias, op. cit., s. 75. 
również postawa państw bałtyckich. Narastaly tam obawy spowodowane podejrzeniami, że przygotowywane porozumienie polsko-niemieckie może dotyczyć także podziału terytorium Łotwy, Litwy i Estonii, między Polskę i III Rzeszę. Spowodowało to nawet interwencję posłów tych państw w Foreign Office, gdzie domagali się oficjalnej deklaracji stwierdzającej, że Wielka Brytania jest zainteresowana w utrzymaniu status quo nad Bałtykiem ${ }^{36}$. Nie trzeba specjalnie udowadniać, że obawy te nie miały żadnych racjonalnych podstaw.

W rozmowie z 18 grudnia z polskim chargé d'affeires w Londynie Lechem Orłowskim naczelnik Wydziału Północnego Fereign Office Collier oświadczył: „W. Brytania żadnej deklaracji tego rodzaju nie zrobi. Nie wynika jednak z tego, byśmy nie byli zainteresowani w utrzymaniu status quo nad Bałtykiem. Będziemy więc zadowoleni, jeżeli ktoś zrobi to za nas".37. Wydaje się, że W. Brytania niechętna zbliżeniu polsko-niemieckiemu, skłaniając Polskę do złożenia oficjalnego oświadczenia w sprawach bałtyckich liczyła na komplikacje w stosunkach polskoniemieckich ${ }^{38}$.

W dniu 19 grudnia J. Łukasiewicz powiadomił M. Litwinowa, że J. Beck akceptuje projekt deklaracji bałtyckiej i zgadza się na jej ogłoszenie w sprzyjających okolicznościach, lecz uzależnia to od postawy państw bałtyckich ${ }^{39}$. Polski minister w instrukcji z 22 grudnia dla polskich placówek w Rydze, Tallinie i Helsinkach polecił zawiadomić tamtejsze rządy z wyraźnym zaleceniem wysondowania ich opinii o polsko-radzieckiej inicjatywie. Równoległy sondaż miała przeprowadzić strona radziecka, przy czym rząd litewski miał być powiadomiony przez Związek Radziecki, natomiast Finlandia przez Polskę ${ }^{40}$. MSZ jednocześnie zastrzegało kategorycznie, że proponowana „deklaracja ma być tylko okolicznościowym stwierdzeniem zgodności stanowisk Polski i ZSRR bronienia pokoju na wschodzie Europy, którego warunkiem jest nienaruszalność terytorium państw bałtyckich. Nie ma być demarchem w Berlinie"41.

Przyjęcie przez Polskę radzieckiej „inicjatywy bałtyckiej” było dobrą okazją dla Litwinowa uczynienia następnego kroku w stosunkach polsko-radzieckich. W rozmowie z Łukasiewiczem 19 grudnia wystąpił z propozycją wizyty Becka w Moskwie. Jego pobyt w stolicy ZSRR byłby według Litwinowa doskonałą okazją do ogłoszenia wspólnej deklaracji w kwestii bałtyckiej, a przede wszystkim do wymiany zdań na temat wytworzonej sytuacji po listopadowym komunikacie Lipski-Hitler. J. Beck zaakceptował sugestię M. Litwinowa i zawiadomił rząd sowiecki o swoim stanowisku już 24 grudnia $^{42}$.

Sprawa wzajemnych radziecko-polskich stosunków znalazła miejsce w oficjalnych wypowiedziach radzieckich polityków na IV Sesji Centralnego Komitetu Wykonawczego ZSRR. J. Mołotow i M. Litwinow wygłosili w dniach 28 i 29 grudnia 1933 r. przemówienia poświę-

\footnotetext{
${ }^{36}$ Rap. polit. Nr 2/34 ambasadora RP w Londynie K. Skirmunta z 23 I 1934 r., ANN, Ambasadora RP w Londynie (dalej: ARP), t. 696, k. 72-75.

${ }^{37}$ Tamże.

${ }^{38}$ M. Wojciechowski, op. cit., s. 82-84.

${ }^{39}$ DIM, t. VI, dok. 91, s. 161-162; tamże, dok. 93, s. 165; zob. też: M. Leczyk, op. cit., s. 344-345.

${ }^{40}$ Tel. szyfr. Nr GMS 8807, 8808, 8809 do placówek polskich w Rydze, Tallinie i Helsinkach, instrukcja J. Becka z 22 XII 1933 r., NNN, MSZ, P III, t. 6764, k. 3; zob. też: B. Budurowicz, Polish-Soviet Relations 1932-1939, Columbia 1963, s. 40, przypis 68.

${ }^{+1}$ Telegr. szyfr. Nr GMS 8827, instrukcja T. Schaetzla z MSZ z 24 XII 1933 r. do poselstwa w Tallinie, ANN, MSZ, P III, t. 6764, k. 7.

42 Telegr. szyfr. Nr GMS 8825 z 24 XII 1933 r., J. Łukasiewicza z MSZ do poselstwa w Moskwie, ANN, MSZ, P III, t. 6764, k. 9.
} 
cone ocenie sytuacji międzynarodowej. Zwracało uwagę stanowisko zajęte wobec Niemiec i Japonii. M. Litwinow zaznaczył, że Związek Radziecki w wypadku naruszenia przez Niemcy pokoju we Wschodniej Europie, będzie bronił nie tylko swoich granic, lecz również ich przyczółków. Zwrócił uwagę na negatywne stanowisko ZSRR wobec zwiększenia potencjału wojskowego Niemiec, oraz wobec planów rewizji granic upozorowanych hasłami walki z „niesłusznymi traktatami”。

Uderzające było w tych wypowiedziach przewartościowanie stosunku do Ligi Narodów i systemu wersalskiego. Związek Radziecki od momentu wystąpienia z Ligi Narodów Japonii (27 III 1933) i Niemiec (14 X 1933), traktować począl Ligę Narodów jako organizację hamującą zamiary agresorów. Litwinow zaznaczył w swoim wystąpieniu, że ZSRR w swojej walce o pokój „gotowy jest wykorzystać istniejące lub mogące powstać organizacje międzynarodowe, o ile będzie miał podstawę sądzić, że służą one sprawie pokoju"43.

W wystąpieniu Litwinowa ustęp poświęcony stosunkom z Polską był nader spolegliwy. Stwierdził, że zawarcie paktu o nieagresji i konwencji o określeniu agresora, przyczyniły się do wzajemnego zaufania i zrozumienia. Litwinow powiedział, że: „polityczne perturbacje w Europie w roku ubiegłym stworzyły wspólnotę interesów, wynikającą ze wspólnego niebezpieczeństwa, ze wspólnych trosk. Jeżeli Polska i my nie zdawaliśmy sobie sprawy ze wspólnoty tych trosk, to podpowiadają je nam ci, którzy nam te troski sprawiają. Wspólne troski i wspólne niebezpieczeństwa są najlepszym cementem lączącym państwa. Szczególnie raduje nas postęp, który dostrzegamy w stosunku polskiego społeczeństwa do naszego Związku, świadczący o tym, że szerokie koła tego społeczeństwa stopniowo dochodzą do przekonania, żywionego przez nas od dawna, że między sąsiadującym Związkiem Sowieckim a Polską jak najściślejsza współpraca jest możliwa i winna mieć miejsce i że nie ma żadnych obiektywnych przyczyn, stojących na przeszkodzie do jej rozwoju. Rok ubiegły był świadkiem niemałych objawów tego zbliżenia" ${ }^{\prime 4}$.

Awanse czynione przez Litwinowa w stosunku do Polski, obliczone były na utrzymanie dotychczasowej linii w polityce polskiej, przede wszystkim na stworzenie czegoś w rodzaju wspólnego frontu polsko-radzieckiego w stosunku do Niemiec. Wykładnikiem tego stanu rzeczy miała być w pojęciu polityków radzieckich deklaracja bałtycka, wiązano też nadzieje z wizytą Becka w Moskwie.

Mimo intencji M. Litwinowa, aby sprawę rokowań o deklarację bałtycką przyspieszyć, dla zachowania tajemnicy ${ }^{45}$, wieść o niej dostała się do opinii międzynarodowej już 4 stycznia

${ }^{43}$ Przegląd informacyjny „Polska a Zagranica”, Nr 1, 8 X 1934 r., s. 12-14, AAN, ARP Londyn, t. 1173; Rap. Nr 52/12/tjn. J. Wszelakiego z 18 XII 1933 r., AAN, MSZ, P II, t. 5205, k. 163-164; zob. też: Raport Nr 3/Sow/1/tjn. H. Sokolnickiego z 2 I 1934 r. do ministra spraw zagranicznych, AAN, ARP Berlin, t. 265, k. 2-6.

${ }^{44}$ Zagadnienia międzynarodowej polityki w oświetleniu premiera Mołotowa i komisarza Litwinowa, zał. do raportu do raportu Nr 3/Sow/1/tjn. H. Sokolnickiego z 2 I 1934 r. do ministra spraw zagranicznych, tamże, k. 7-14.

${ }^{45}$ Telegr. szyfr. Nr GMS 4157 H. Sokolnickiego z 26 XII 1933 r. do MSZ, ANN, MSZ, P III, t. 6764, k. 111. 
1934 r. za sprawą organu Labour Party, „Daily Herald”46. Sugestia M. Wojciechowskiego ${ }^{47}$, że informacja ta ukazała się za sprawą czynników radzieckich, nie wydaje się prawdopodobna. Świadczy o tym zarówno dążenie Litwinowa do zachowania tajemnicy, jak i zdenerwowanie strony radzieckiej wywołane rewelacjami „Daily Herald”48.

Głównym inspiratorem wiadomości podanych przez „Daily Herald” była Finlandia, na co wskazuje jej zdecydowanie negatywny stosunek do polsko-radzieckiego projektu deklaracji bałtyckiej ${ }^{49}$, jak również polska demarche, stwierdzająca, że wobec „niedyskrecji czynników oficjalnych” rząd polski nie może w stosunkach z rządem fińskim „opierać współpracy na zasadzie zaufania i poufności"s0.

W Niemczech reakcja na wiadomości podane przez „Daily Herald” była natychmiastowa. Niemiecka agencja urzędowa „Deutsche Nachrichten - Büro” 4 stycznia ogłosiła komunikat, który mówił, że „Wiadomość zamieszczona w londyńskim «Daily Herald» o skierowanych przeciwko Niemcom planach akcji ze strony Rosjan i Polaków w krajach sąsiednich (Randstaaten) ma odpowiadać zamiarom miarodajnych kół w obu tych krajach" (tzn. w Polsce i ZSRR) ${ }^{51}$.

Był to ze strony Niemiec nacisk obliczony na przyspieszenie terminu podpisania deklaracji o nieagresji z Polską w formie najbardziej korzystnej dla Rzeszy ${ }^{52}$.

W związku z tym komunikatem J. Beck 4 stycznia udzielił instrukcji J. Lipskiemu: „W razie potrzeby oświetlenia wobec rządu niemieckiego wiadomości podanej przez prasę o rozmowach polsko-sowieckich co do państw bałtyckich, proszę spokojnie wyjaśnić, że nowe, powojenne pań-

${ }^{46} \mathrm{~W}$ artykule „Daily Herald” pt. „Polski plan zamknięcia drogi Hitlerowi” napisano: „Nowy ważny system bezpieczeństwa, który stanowiłby skuteczną zaporę dla wszelkich hitlerowskich planów ekspansji na wschód projektowany jest obecnie w Moskwie i w Warszawie. Litwinow zaproponowal rządowi polskiemu, aby Związek Radziecki i Polska łącznie zagwarantowały niepodległość i integralność czterech państw limitrofów: Finlandii, Estonii, Łotwy i Litwy. Przyjęcie przez Polskę takiej propozycji można uważać za pewne. Gwarancje jakie te cztery państwa posiadają z tytułu paktu Ligi Narodów, uległyby więc wzmocnieniu przez sojusz polsko-sowiecki dla utrzymania pokoju we wschodniej Europie. Posunięcie sowieckie jest bezpośrednim skutkiem groźby polityki hitlerowskiej znalezienia terytoriów na wschodzie dla ekspansji narodu nie posiadającego doń zaplecza", Polska Agencja Telegraficzna, Biuletyn Informacyjny „Do Wiadomości”, Nr 3, 4 I 1934, ANN, MSZ, P III, t. 6764, k. 29.

${ }^{47}$ Zob. M. Wojciechowski, op. cit., s. 101.

48 „Izwiestija” z 5 I 1934, nr 5 opublikowały dementi TASS w związku z artykułem „Daily Herald”: „informacja «Daily Herald», jakoby ZSRR i Polska miały zawrzeć pomiędzy sobą pakt bezpieczeństwa, włączając gwarancje granic państw bałtyckich i skierowany przeciwko planom niemieckiej ekspansji na Wschód, nie odpowiada rzeczywistości"; zob. też: telegr. szyfr. Nr GMS $55 \mathrm{H}$. Sokolnickiego do MSZ z 5 I 1934 r., AAN, MSZ, P III, t. 6764, k. 114.

${ }^{49}$ Minister spraw zagranicznych Finlandii Heckzell poinformował posła polskiego Fr. Charwata 27 XII 1933 r., że Finlandia „zrzeka się wszelkich deklaracji gwarancyjnych ze strony ZSRR i nie chce stanowczo być wciągnięta w sferę zainteresowań i akcji politycznych ze strony ZSRR. Uważa deklarację za niebezpieczną dla swych interesów, bo stworzyć ona może za granicą opinię o istniejącym tu niebezpieczeństwie dla pokoju, a w konsekwencji utrudnić kredyty - tym samym i tak ciężkie warunki ekonomiczne. Telegr. szyfr. Nr GMS 4169 Fr. Charwata z 27 XII 1933 r., AAN, MSZ, P III, t. 6764, k. 13; por. pismo J. Lipskiego z 4 I 1934 r. do MSZ, AAN, MSZ, P III, t. 6764, k. 28-29.

${ }^{50}$ Telegr. szyfr. Nr GMS 5064 T. Schaetzla z 8 I 1934 r. do Poselstwa RP w Hełsinkach, AAN. MSZ, P III, t. 6764, k. 39.

${ }^{51}$ Cyt. za M. Wojciechowskim, op. cit., s. 101; Por. W. Materski, op. cit., s.279.

\$2 Tamże, zob. też: K. Lapter, op. cit., s. 16. 
stwa bałtyckie były do niedawna terenem sprzeczności polityki Sowietów i Polski. Sprzeczność ta została usunięta w związku z ogólną poprawą stosunków. Zostało to wyjaśnione w rozmowach między nami a Moskwą. Rozmów tych nie należy identyfikować, z jakimś bałtyckim ogólnym planem. Problem bałtycki interesuje nas istotnie, w razie poruszenia go jako całości nie pominęlibyśmy jednak Niemiec".53.

Stwierdzenie J. Lipskiego w rozmowie z ministrem spraw zagranicznych Niemiec Konstantinem Neurathem, że rozmowy polsko-radzieckie przyczyniły się do usunięcia sprzeczności między Polską i Związkiem Radzieckim, było, jak twierdzi M. Wojciechowski, usiłowaniem zachoẃania przez Polskę pozycji przetargowej w rokowaniach o tekst deklaracji o nieagresji ${ }^{54}$.

Świadczy o tym również wypowiedź J. Becka udzielona 6 stycznia 1934 r. dziennikarzowi „Excelsior” na temat stosunków polsko-radzieckich. „Uważam, że zbliżenie polsko-sowieckie jest wzorem akcji, mającej na celu poszukiwanie nowych dróg, które zamiast gubić się wśród małych trudności, będą zmierzać do osiągnięcia pozytywnego rezultatu. Nasze stosunki z Sowietami rozwijały się logicznymi etapami, z których każdy zaznaczony jest ważną deklaracją lub dokumentem politycznym.

Podpisaliśmy szereg aktów w ciągu ostatniego roku i każde z tych wydarzeń politycznych było rezultatem ewolucji, odbywało się w doskonałej harmonii z rozwojem rzeczywistym tych stosunków i czynnym współdziałaniem obu rządów. Jest to akcja, która daje mi dużo zadowolenia, i którą uważam za potężny czynnik w dziedzinie stabilizacji Europy Wschodniej. Znaleźliśmy szczęśliwie nową drogę, po której postępujemy logicznie i metodycznie naprzód”’s."

Dnia 9 stycznia 1934 r. J. Lipski wręczył K. Neurathowi polski kontrprojekt deklaracji o nieagresji ${ }^{56}$. Lipski jeszcze raz podkreślił, że polsko-radzieckie negocjacje dotyczyły zbliżenia punktów widzenia obu państw w zagadnieniach bałtyckich i nie miały żadnego charakteru antyniemieckiego. Neurath zauważył, że projekt deklaracji bałtyckiej wynikł ze zdenerwowania Litwinowa zbliżeniem polsko-niemieckim. Stwierdził, że „wątpi, by dla Polski taka wspólna z Rosją gwarancja państw bałtyckich była dobrym interesem, dodając, że mogłoby to nas w przyszłości narazić na pewne z Rosją komplikacje”.57. Wydaje się, że uspokajająca wypowiedź Lipskiego co do stosunków polsko-radzieckich, miała wpływ na przyspieszenie polsko-niemieckich negocjacji, które od tego momentu weszły w nową fazę ${ }^{58}$.

Komunikat „Daily Herald” z 4 stycznia nie wywołał w Warszawie większego zdenerwowania. Oficjalne stanowisko rządu zostało przedstawione w artykule redakcyjnym "Igły i widły” na łamach „Gazety Polskiej” z 7 stycznia. Półoficjalny organ rządowy pisał, że: „nie ma między Polską a ZSRR rokowań o nowy "pakt » dotyczący Nadbałtyki. Nie ma również we wzajemnej pracy dyplomatycznej Polski i ZSRR nic, co by zawierało ostrze agresji skierowane przeciw komukolwiek, a w szczególności przeciw Niemcom... Artykuł «Daily Herald» jest więc

${ }^{53}$ Telegr. szyfr. Nr GMS 5028 J. Becka z 4 I 1934 r. do Poselstwa RP w Berlinie, AAN, MSZ, P III, t. 6764, k. 23.

${ }^{54}$ M. Wojciechowski, op. cit., s. 102.

55 J. Beck, Przemówienia, deklaracje, wywiady 1931-1939, Warszawa 1939, s. 92-93.

${ }^{56} \mathrm{~K}$. Lapter, Dokumenty dotyczqce genezy polsko-niemieckiej deklaracji o niestosowaniu przemocy $z 26$ I 1934 r. (Z archiwum Józefa Lipskiego), „Studia z Najnowszych Dziejów Powszechnych”, 1963, t. V, dok. XXX.

${ }^{57}$ Rap. Nr 128/1/34 J. Lipskiego z 11 I 1934 r., AAN, MSZ, P III, t. 6764, k. 45-50.

${ }^{58}$ Tamże. 
na pewno w znacznej mierze wynikiem tego, że wbrew nadziejom wielu «zmorfinizowanych» polityków stosunki między Polską i ZSRR rozwijają się i zacieśniają nadal"sy.

Komentarz „Gazety Polskiej” spowodowaṇy był ukazaniem się dementi TASS w „Izwiestijach” z 5 stycznia. Oficjalnie strona polska twierdziła, że „niepodległość Państw Bałtyckich oraz jej utrzymanie - było od dawna, jest i będzie zasadą polityki polskiej nad Bałtykiem" "

Równocześnie w stosunku do Związku Radzieckiego Polska wystąpiła z inicjatywą rozszerzenia liczby gwarantów niepodległości państw bałtyckich, także na Niemcy. Litwinow nie wyraził sprzeciwu, aby inne państwa przyjęły udział w deklaracji, podkreślił jednak, że mogłoby to nastąpić w formie przystąpienia ich do deklaracji polsko-radzieckiej po jej ogłoszeniu, a nie $\mathrm{w}$ formie udziału jakiegokolwiek państwa trzeciego w pracach przygotowawczych ${ }^{61}$.

Krok Polski podyktowany był stanowiskiem Niemiec wobec projektu deklaracji bałtyckiej. Wysuwając postulat przystąpienia Niemiec, Polska dążyła do uspokojenia Rzeszy. Deklaracja bałtycka straciłaby tym samym swój antyniemiecki charakter, wobec czego oponował Litwinow. Był on poinformowany poufnie przez Łukasiewicza (11 stycznia), że rokowania polsko-niemieckie są bardzo zaawansowane, dlatego też nalegał na szybkie sfinalizowanie deklaracji bałtyckiej. Starania strony radzieckiej wywołały w Auswärtiges Amt zaniepokojenie ${ }^{62}$. W Berlinie zdawano sobie sprawę, że Polska traktuje projekt radziecki jako środek presji na Niemcy w celu przyspieszenia rokowań w sprawie deklaracji o niestosowaniu przemocy. Obawy przed wspólną polityką polsko-radziecką nad Bałtykiem, zmusiły - według Lipskiego - „oporne czynniki Amtu do przyśpieszenia finalizacji deklaracji"6.3.

Dla Polski kwestia deklaracji bałtyckiej, po podpisaniu 26 stycznia 1934 r. deklaracji o niestosowaniu przemocy z Niemcami ${ }^{64}$, przestała być aktualna. Dalsze rozmowy na ten temat mogły wpłynąć niekorzystnie na odprężenie osiągnięte w stosunkach polsko-niemieckich. J. Beck zaczął więc wycofywać się, wykorzystując niejednolite stanowisko państw bałtyckich wobec projektu radzieckiego. Zdecydowanie negatywne stanowisko Finlandii, oficjalnie chłodne postawy Estonii i Łotwy ${ }^{6.5}$, a przede wszystkim wypowiedź premiera Litwy Dowasa Zauniusa, który miał powiedzieć, że deklaracja bałtycka stwarza podstawę do poruszenia ponownego sprawy Wilna, stwarzały według Becka poważne komplikacje ${ }^{66}$.

Dnia 3 lutego 1934 r. poseł polski w Moskwie powiadomił oficjalnie Litwinowa, że Polska uważa deklarację bałtycką za nieaktualną z powodu zdecydowanie negatywnego stanowiska

5y „Gazeta Polska” (dalej: „GP”), Nr 7 z 7 I 1934 r.

${ }^{60}$ Tamże.

${ }^{61}$ Rap. Nr 49/Sow/4 J. Łukasiewicza z 16 I 1934 r., AAN, MSZ, P III, t. 6764, k. 54-58.

62 Informacji o rozmowach polsko-radzieckich udzielił M. Litwinow 15 I 1934 r. ambasadorowi Rzeszy w Moskwie Rudolfowi Nadolnemu. Starał się on zbadać aktualny stan zbliżenia między Polską a Związkiem Radzieckim, Raport Nadolnego do Auswärtiges Amt z 16 I 1934 r., DGFP, Series C, vol II, dok. 187; zob. też: Raport Nr 49/Sow/4 J. Łukasiewicza z 16 I 1934 r. do ministra spraw zagranicznych, AAN, MSZ, P III, t. 6764, k. 54-58.

${ }^{63}$ List J. Lipskiego do ministra Becka z 5 II 1934 r., Diariusz i teki Jana Szembeka (dalej: DTJS), t. I, Londyn 1964, dok. 55, s. 137.

${ }^{64}$ Zob. na przykład: K. Lapter, Pakt Pitsudski-Hitler. Polsko-niemiecka deklaracja o niestosowaniu przemocy z 26 stycznia 1934 r., Warszawa 1962; tenże, Dokumenty..., M. Wojciechowski, op. cit.; J. Lipski, Papers and Memoires of... Diplomat in Berlin 1933-1939, New York and London 1968.

${ }_{6.5}$ Telegr. szyfr. Nr 41/tjn./34, Instrukcja J. Becka dla J. Łukasiewicza z 30 I 1934 r., AAN, MSZ, P III, t. 6764, k. 110 .

${ }^{66}$ DIM, t. VI, dok. 101, s. 173-174. 
Finlandii, kategoryczności dementi radzieckiego z 4 stycznia, co według Polski utrudnia ponawianie akcji dyplomatycznej i reakcji Litwy, czego przejawem było wystąpienie D. Zauniusa ${ }^{67}$. M. Litwinow odpowiadając na argumenty Łukasiewicza stwierdził, że postępowanie Polski w stosunku do Związku Radzieckiego jest zawsze jednakowe. „Polega ono na tym, że dając w pierwszej chwili zgodę zasadniczą, Polska stawia później warunki, które albo stwarzają poważne trudności i sprawę odwlekają, albo też uniemożliwiają prawie doprowadzenie jej do skutku. Tak było z paktem o nieagresji, konwencją o określeniu napastnika i wreszcie z deklaracją bałtycką"68.

Według Litwinowa, odrzucenie przez Becka deklaracji bałtyckiej sprowadzało perspektywy współpracy polsko-radzieckiej do nieznacznego minimum ${ }^{69}$. Mówiąc o bliskiej wizycie Becka w Moskwie powiedział, że ma wątpliwości „czy Pan Minister zechce mówić z nim co do sprawy deklaracji, o sprawach bałtyckich, czy też może mówić już o tem z «kimś innym»"7》. Dyplomacja radziecka była zaniepokojona polityką polską, zwłaszcza jej stosunkiem do Niemiec i państw bałtyckich. Obawiano się możliwości „niespodzianek zygzaków polityki w Polsce”71. Odpowiedziała na to „Gazeta Polska”, pisząc, że „najkrótszą, choć może nienajłatwiejszą była droga, którą polityka polska poszła do celu - droga bezpośredniego układu, wykluczającego wojnę z obu sąsiadami. I dlatego linia ta skierowana jest najpierw na wschód, a następnie na zachód - jedynie geograficznie była «zygzakiem» - politycznie była zaś linią prostą, jako najkrótsza droga do celu"7?

W kilka dni później „Izwiestija” stwierdzały, że gdyby polityka III Rzeszy była szczera, oznaczałoby to zmianę w jej dotychczasowej polityce zagranicznej. „Musiało również powstać pytanie - pisały „Izwiestija” - jakie kompensacje i na czyj koszt były obiecane Niemcom, by wyrzekły się zmiany granic przy zastosowaniu przemocy. Rezygnacja jest jednoznaczna z uznaniem ostatecznym obecnych granic niemiecko-polskich, ponieważ jest mało prawdopodobne, by Polska zgodziła się dobrowolnie na nowy podział swego terytorium. Sprawa ta musi interesować nie tylko jedno państwo sąsiadujące z Polską"73.

W ZSRR odprężenie w stosunkach polsko-niemieckich wywołało uczucie pewnego zawodu. Widoczne to było w komentarzach prasowych na temat deklaracji polsko-niemieckiej, które chociaż zaznaczając, że akt ten stanowi z punkфı widzenia polityki pokojowej znaczny postęp, zapytywały jednocześnie „czy jawne odstępstwo od głoszonych zasad ze strony Niemiec nie kryje za sobą obietnic pewnych rekompensat"74 dla Polski kosztem Związku Radzieckiego.

${ }^{67}$ Telegr. szyfr. Nr 5484 do Poselstwa Ryga i 5385 do Poselstwa Tallin, Instrukcja J. Szembeka z 12 II 1934 r., AAN, MSZ, P III, t. 6764, k. 70.

${ }^{68}$ Raport Nr 49/Sow/9/tjn./ J. Kukasiewicza z 5 II 1934 r. do ministra spraw zagranicznych, AAN, MSZ, P III, t. 6764, k. 143-151.

${ }^{69}$ Raport Nr 49/Sow/12/ś.tjn./ J. Łukasiewicza z 20 II 1934 r. do ministra spraw zagranicznych, AAN, MSZ, P III, t. 6764, k. 173-181.

70 Raport $\mathrm{Nr}$ 49/Sow/9/tjn/ J. Łukasiewicza z 3 II 1934 r. do ministra spraw zagranicznych, AAN, MSZ, P III, t. 6764, k. 143-151.

7 Referat sprawozdawczy KC WKP(b) na XVII Zjazd WKP(b), J. Stalin, Dzieta, t. 13, Warszawa 1951, s. 306-308; zob. też: „Polska a Zagranica”, Nr 5, 5 II 1934, AAN, ARP Londyn, t. 1173, k. 8284; DIM, t. VI, dok. 99, s. 170-171; J. Zacharias, op. cit., s. 78.

72 „GP”, Nr 30 z 30 I 1934 r.

7.3 "GP”, Nr 30 z 30 I 1934 r., zob. też: DIM, t. VI, s. 178, przyp. 3.

${ }^{74}$ Rap. Nr 3/Sow/3/tjn./ J. Łukasiewicza z 30 I 1934 r., AAN, MSZ, P III, t. 6649, k. 84-90; por. M. Beloff, The Foreign Policy of Soviet Russia 1929-1941, London 1955, t. I, s. 140. 


\section{Wizyta Józefa Becka w Moskwie}

Stanowisko ZSRR wobec Polski na kilkanaście dni przed wizytą polskiego ministra w Moskwie J. Łukasiński charakteryzował następująco: „Politykę sowiecką w stosunku do nas charakteryzowały w ciągu ostatniego roku dwa zasadnicze momenty: Primo - daleko posunięta szczerość $\mathrm{w}$ omawianiu $\mathrm{z}$ nami $\mathrm{w}$ rozmowach zarówno oficjalnych, jak i nieoficjalnych niebezpieczeństwa niemieckiego i w chęci przekonania nas o tym, że niebezpieczeństwo to, rosnąc $\mathrm{z}$ dnia na dzień, musi w stosunkowo niedalekiej przyszłości doprowadzić do konfliktu zbrojnego pomiędzy nami a Rzeszą Niemiecką kierowaną przez Hitlera. Secundo - wyraźnie dążenie w rozmowach głównie nieoficjalnych, prowadzonych z inicjatywy sowieckiej przez czynniki partyjne i prasowe, do szybkiego posuwania naprzód procesu zbliżenia pomiędzy nami, z chęcią doprowadzenia do czegoś w rodzaju sojuszu politycznego, który dałby rządowi sowieckiemu gwarancję niezmienności naszego negatywnego stosunku do Niemiec hitlerowskich"7.5.

W takiej sytuacji doszła do skutku oficjalna wizyta w Moskwie polskiego ministra spraw zagranicznych. Mówiąc o aktualnym stanie stosunków z ZSRR, 5 lutego 1934 r., w Komisji Spraw Zagranicznych Senatu Beck powiedział, że brak agresywnych tendencji między Polską a Związkiem Sowieckim wytworzył atmosferę, w której zanikały sprzeczne tendencje politycz$\mathrm{ne}^{76}$. Wypowiedź ta miała głównie na celu stworzenie odpowiedniego klimatu dla planowanej moskiewskiej wizyty. W rzeczywistości bowiem Beck nie przewidywał szczególnego zbliżenia do ZSRR. Możliwość taką wykluczała ścisła instrukcja otrzymana przed wyjazdem do Moskwy od marszałka Piłsudskiego: „Należy stworzyć atmosferę szczególnie swobodnych, a nawet przyjaznych manifestacji, równocześnie jednak być ostrożnym i nie dać się wciągnąć na śliską drogę współpracy politycznej z Sowietami"77.

Z wachlarza problemów, które Beck zamierzał omówić z Litwinowem kategorycznie wyłączył on kwestię deklaracji bałtyckiej, uważając ją za nieaktualną, jak i wszelkie zagadnienia mogące mieć charakter antyniemiecki ${ }^{78}$. Głównym celem wizyty polskiego ministra w Moskwie było zamanifestowanie niezależności polskiej polityki, wywołanie wrażenia równorzędności na linii „Warszawa-Berlin” i „Warszawa-Moskwa”, oøaz podniesienie wartości Polski w oczach Niemiec $^{79}$. J. Beck chciał również zaakcentować wobec ZSRR, że zawarcie deklaracji o niestosowaniu przemocy z III Rzeszą nie wpłynęło ujemnie na stosunki polsko-radzieckie. Te akcenty wizyty szefa polskiej dyplomacji podkreśliła „Gazeta Polska”, pisząc, że „wizyta uważana jest powszectınie za objaw dalszego zblizenia polsko-sowieckiego, będąc zarazem zaprzeczeniem pogłosek części prasy zagranicznej, jakoby stosunki polsko-sowieckie miały ulec pogorszeniu na skutek polsko-niemieckiego układu o nieagresji" ${ }^{100}$.

${ }^{75}$ Rap. Nr 49/Sow/10/tjn. J. Łukasiewicza z 4 II 1934 r., AAN, MSZ, P III, t. 6764, k. 154-169.

$76 \mathrm{~J}$. Beck, Przemówienia, deklaracje, wywiady..., s. 98.

77 Cyt. za M. Wojciechowskim, op. cit., s. 122.

${ }^{78}$ List Dyrektora Gabinetu Ministra R. Dębickiego z 6 II 1934 r. do J. Lipskiego, DT JS, t. I, dok. 2, s. $137-138$.

${ }^{79}$ H.L. Roberts, The Diplomacy of Colonel Beck, [w:] The Diplomats 1919-1939, ed. G.A. Craig, F. Gilbert, Princeton 1953, s. 607; S. Jaworznicki, Pakt Wschodni, „Sprawy Międzynarodowe”, 1949, nr 3/4, s. 94.

so „GP”, Nr 40 z 9 II 1934 r. 
Polski minister chciał również zaakcentować wobec ZSRR, że zawarcie deklaracji o niestosowaniu przemocy z Niemcami nie wpłynęło bynajmniej na pogorszenie stosunków polsko-radzieckich. Wizyta doszła do skutku w dniach 13-15 lutego 1934 r. Był to pierwszy pobyt polskiego ministra spraw zagranicznych w Moskwie. Oficjalnie stanowił rewizytę za pobyt ludowego komisarza spraw zagranicznych Gieorgija Cziczerina w 1925 r. w Warszawie. Przyjęcie zgotowane polskiemu ministrowi w Moskwie było uroczyste i przyjazne.

Przyjazd J. Becka do Moskwy poprzedziło kilka artykułów w prasie radzieckiej, traktujących o polityce Polski i stosunkach polsko-radzieckich w życzliwy sposób ${ }^{81}$. „Izwiestija” z 12 II 1934 r. podkreślały, że głównym kierunkiem polityki polskiej było unormowanie stosunków z Sowietami i nawiązanie trwalszych więzi pomiędzy społeczeństwami obydwu państw. Wizyta Becka ma na celu utrwalenie tych stosunków, co wpłynie niewątpliwie na stabilizację sytuacji w Europie Wschodniej - podkreślały „Izwiestija”.

W okresie pobytu polskiego ministra w Moskwie, prasa radziecka podawała szczegółowe etapy jego wizyty ${ }^{82}$. Nieprzypadkowe wydaje się przypomnienie przez dzienniki moskiewskie słów Wyspiańskiego: „niech na całym świecie wojna, byle polska wieś zaciszna, byle polska wieś spokojna"\$3 jako motto pokojowej polityki zagranicznej Polski i jednocześnie sugerujące w ten sposób korzyści, jakie Polska może odnieść za stan dobrosąsiedzkich stosunków z ZSRR.

Zagadnienia, jakie poruszyli obaj ministrowie dotyczyły kilku problemów, mianowicie: stosunków polsko-niemieckich, kwestii bałtyckiej, rozbrojenia oraz stosunków bilateralnych.

Poruszając zagadnienia polsko-niemieckiej deklaracji z 26 stycznia, M. Litwinow, mimo początkowo chłodnej postawy wobec zbliżenia polsko-niemieckiego, uznał jednak, że przynosi ona spadek napięcia w stosunkach Polski z Rzeszą i zamyka kwestię Pomorza, co zdaniem jego nie przeciwstawiało się zupełnie interesom Związku Radzieckiego ${ }^{84}$. Dyplomacja radziecka ostrzegała jednak Polskę przed łudzeniem się chwilowymi sukcesami i wyciąganiem zbyt pochopnych wniosków z sytuacji wewnętrznej w Niemczech. M. Litwinow zwracał uwagę J. Becka, że Hitler nie wyrzekł się programu, którego podstawowym ogniwem było włączenie do Niemiec „polskiego korytarza" ${ }^{\text {sj. }}$

Nie zgadzał się również z Beckem, że odejście od władzy w Rzeszy Prusaków, otworzyło nowy okres w stosunkach polsko-niemieckich. „Pruski duch - mówił M. Litwinow - panuje teraz w całych Niemczech. U podstaw ideologii Niemiec leży ich sprusaczenie. Pruskie maksymy o konieczności znalezienia sobie miejsca pod słońcem, o nadmiarze ludności, której trzeba znaleźć swoje terytoria dla kolonizacji, gloryfikacja wojennego ducha i wojennych podbojów znajdują najbardziej jaskrawy wyraz w poglądach hitlerowców"s6.

M. Litwinow zwrócił uwagę J. Becka, że deklaracja polsko-niemiecka wywołała duże zaniepokojenie wśród państw bałtyckich ${ }^{87}$. W stwierdzeniu tym kryła się równocześnie aluzja do odrzucenia przez Polskę deklaracji bałtyckiej. Beck uważał jednak to zagadnienie za zupełnie

81 „Izwiestija” z 7 II 1934 r.

${ }^{82}$ Rap. Nr 323/Sow/L/1 J. Łukasiewicza z 20 II 1934 r., AAN, MSZ, P IV, t. 7084, k. 151-153.

83 „Izwiestija” 13 i 14 II 1934 r.; cyt. za A. Skrzypkiem, op. cit., s. 37.

${ }^{84}$ List posła J. Lipskiego do ministra Becka z 16 II 1934 r. o rozmowie z ambasadorem ZSRR w Berlinie Lwem Chińczukiem, DTJS, t. I, dok. 58, s. 141-142.

${ }^{8.5}$ Notatka Litwinowa z rozmowy z Beckiem z 13-15 XII 1934 r., DIM, t. VI, s. 186.

${ }^{86}$ Tamże, cyt. za M. Leszczykiem, Polityka II Rzeczypospolitej..., s. 351.

${ }^{87}$ Tamże; telegr. szyfr. Nr GMS 395 J. Łukasiewicza z 7 II 1934 r. do MSZ, AAN, MSZ, P III, t. 6764, k. 171. 
nieaktualne i nie przychylił się do wniosku Litwinowa, zaznaczenia wspólnego stosunku Polski i ZSRR do problemu bałtyckiego w oficjalnym komunikacie o przebiegu jego wizyty w Moskwie ${ }^{8 x}$.

Stanowisko Becka wobec zàgadnienia bałtyckiego, zrodziło podejrzenie Litwinowa - na co zwrócił uwagę Łukasiewicz - ze istotnym celem polityki Polski w stosunku do państw bałtyckich „jest wyeliminowanie zupełnie z tego terenu zarówno wpływów politycznych Berlina, jak i Moskwy" ". Wniosek ten wydają się potwierdzać późniejsze próby dyplomacji polskiej stworzenia bloku politycznego tzw. „Trzeciej Europy”.

Odrzucenie przez Polskę próby zbliżenia z ZSRR na płaszczyźnie bałtyckiej spowodowało wysunięcie analogicznej propozycji Moskwy pod adresem Berlina - to jest podpisania deklaracji gwarantującej niepodległość państw bałtyckich. Ta propozycja została przedłożona 28 marca 1934 r. ambasadorowi Niemiec w Moskwie - Rudolfowi Nadolnemu.

Niemcy 14 kwietnia 1934 r. odrzuciły jednak propozycję radziecką, twierdząc, że państwom bałtyckim nic nie zagraża ${ }^{90}$. W propozycji radzieckiej $M$. Beloff dopatruje się próby wybadania przez M. Litwinowa, czy Niemcy i Polskę nie łączyło tajne porozumienie wojskowe ${ }^{91}$. Propozycja radziecka skierowana do Niemiec była próbą zmierzającą do zmniejszenia napięcia w Europie. Odrzucenie jej podważało zapewnienia Hitlera o pokojowej polityce Rzeszy.

W czasie rozmów moskiewskich J. Beck wypowiedział się negatywnie o zbrojeniach niemieckich. Zgodził się z M. Litwinowem, że istnieje niebezpieczeństwo przekształcenia genewskiej konferencji rozbrojeniowej w konferencję dozbrojeniową. Pominął jednak sugestię radzieckiego rozmówcy uzgodnienia wspólnego stanowiska obu państw wobec problemów międzynarodowych $^{\text {92 }}$. Dla zrównoważenia nikłych efektów rozmów moskiewskich, Beck wystąpił z propozycją podniesienia przedstawicielstw dyplomatycznych obu państw, w Moskwie i w Warszawie, do rangi ambasad. Projekt polskiego ministra został przychylnie przyjęty przez stronę radziecką ${ }^{{ }^{43}}$.

M. Litwinow dążył do wykorzystania w rozmowach każdego środka, mogącego zrównoważyć zbliżenie polsko-niemieckie. W rozmowach z polskim ministrem poruszył problem przedłużenia polsko-radzieckiego paktu o nieagresji z 25 lipca 1932 r. J. Beck zaakceptował ten postulat, ale uchylił się od jego natychmiastowego sfinalizowania, to jest podczas swojej wizyty w Moskwie ${ }^{94}$. Spróbował natomiast powiązać kwestię przedłużenia polsko-radzieckiego paktu o nieagresji na dziesięć lat z zawarciem odpowiedniej umowy rumuńsko-radzieckiej, co napotkało sprzeciw ze strony radzieckiej5.

${ }^{8 *}$ Tamże.

${ }^{89}$ Raport Nr 49/Sow/12/ś.tjn/ J. Łukasiewicza do ministra spraw zagranicznych z 20 II 1934 r., AAN, MSZ, P III, t. 6764, k. 173-181.

${ }^{9}{ }^{0}$ M. Leczyk, op. cit., s. 353.

${ }^{91}$ M. Beloff, op. cit., s. 141; zob. też: M. Leczyk, Polityka II Rzeczypospolitej..., s. 353.

${ }^{92}$ Przemówienie Litwinowa z 14 II 1934 r., DIM, t. VI, s. 184.

9.3 Podniesienie przedstawicielstw dyplomatycznych w Warszawie i Moskwie do rangi ambasad nastąpiło 10 IV 1934 r., W. Michowicz, Walka dyplomacji polskiej przeciwko traktatowi mniejszościowemu w Lidze Narodów w roku 1934, Łódź 1963, s. 43.

${ }^{94}$ DIM, t. VI, dok. 107, s. 175-191.

${ }_{95}$ Tamże, dok. 109, s. 195; por. A. Skrzypek, Zagadnienia rumuńskie $w$ stosunkach polsko-radzieckich w latach 1932-1938, w: „Z dziejów...”, t. XI-XII, s. 197; szerzej o stosunkach rumuńsko-radzieckich w tym okresie zob.: J.M. Kopański, J.E. Lewit, Sowietsko-rumynskije otnoszenija 1929-1934, Moskwa 1971; A.A. Szewiakow, Sowietsko-rumynskije otnoszenija i problema ewropiejskoj biesopasnosti 1932-1938, Moskwa 1977, s. 94-135. 
Spotkanie ministrów - polskiego i radzieckiego - było zajmującym spektaklem gry dyplomatycznej. Stanowisko Becka w toku tych rozmów zmierzało do stworzenia korzystnej dla Polski koniunktury politycznej na linii Moskwa-Warszawa-Berlin. Litwinow - polityk nie mniej od Becka inteligentny - właściwie ocenił, że kierownicy polskiej polityki zagranicznej, J. Piłsudski i J. Beck nie przewidują dalszych porozumień ze wschodnim sąsiadem, liczą natomiast na korzyści płynące z trudnej sytuacji ZSRR na arenie międzynarodowej. Uważał, że Polska czując się zabezpieczona na pewien czas ze strony Niemiec, maskuje swój kurs na blizsze stosunki z Niemcami podtrzymaniem na zewnątrz przyjaznych stosunków z ZSRR. Twierdził, że jest to jednak korzystne także dla Związku Radzieckiego, bowiem w przyszłości może utrudnić przejście rządu polskiego na pozycje wrogie wobec ZSRR. Sugerował, że z tego względu należy podtrzymywać pozory dobrych stosunków i w dalszym ciągu rozwijać kontakty kulturalne z szerokimi kręgami społeczeństwa polskiego ${ }^{y 6}$. Obaj uczestnicy tej gry stanęli na wysokości zadania.

\section{Przedłużenie polsko-radzieckiego paktu o nieagresji}

Kwestię prolongaty polsko-radzieckiego paktu o nieagresji Polska starała się powiązać z równoczesnym przedłużeniem paktów o nieagresji Związku Radzieckiego z państwami bałtyckimi i podpisaniem analogicznego radziecko-rumuńskiego paktu ${ }^{97}$. Szczegółowo pisze na ten temat Marian Leczyk, wysuwając tezę, że propozycja Polski w tym zakresie była odbiciem nadziei na stworzenie bloku tj. porozumienia „solidarnościowego” u zachodniej granicy ZSRR $^{\text {98. }}$. Polska występowała więc wobec ZSRR z tezą o potrzebie łączności wszystkich paktów o nieagresji, zawartych przez Związek Radziecki ze swoimi zachodnimi sąsiadami w jeden system stabilizujący stosunki polityczne w Europie Wschodniej. Ponownie kwestia zawarcia paktu o nieagresji radziecko-rumuńskiego, poruszona została przez J. Łukasiewicza 20 lutego 1934 r. w rozmowie z M. Litwinowem, a wypływała ze stanowiska strony polskiej, że brak takiego układu stanowi lukę w systemie paktów zawartych w 1932 r. ${ }^{9 y} \mathrm{~W}$ wystąpieniu J. Łukasiewicza znajdowała wyraz chęć odegrania przez Polskę roli pośrednika w sprawie regulacji stosunków radziecko-rumuńskich, co pozostawało w związku ze wspomnianym wyżej blokiem wzdłuż zachodnich granic ZSRR: od Finlandii do Rumunii.

Problem rumuński, wskutek odmiennych planów ministra spraw zagranicznych Rumunii Nicolae Titulescu, który pakt o nieagresji z ZSRR w ówczesnej fazie stosunków między obu państwami uważał za błędny, został zdezaktualizowany ${ }^{100}$.

${ }^{96}$ DIM, t. VI, dok. 107, s. 192; zob. też: M. Leczyk, op. cit., s. 354.

${ }^{97}$ Raport Nr 49/Sow/12/ś.tjn/ J. Łukasiewicza dla ministra spraw zagranicznych z 20 II 1934 r., AAN, MSZ, P III, t. 6764, k. 173-181; notatka M. Litwinowa z rozmowy z J. Łukasiewiczem 20 II 1934 r., DWP, t. XVII, s. 154-157.

${ }^{{ }^{*}}$ M. Leczyk, op. cit., s. 355.

99 Tamże; por. też: W. Lipiński (Gwido), Polityka zagraniczna J. Pitsudskiego i J. Becka, (Próba syntezy), Warszawa 1943 , s. $35-36$.

${ }^{100}$ Raport Nr 49/Sow/12/ś.tjn/ J. Łukasiewicza dla ministra spraw zagranicznych z 20 ll 1934 r., AAN, MSZ, P III, t. 6764, k. 173-181; zob. też: A. Skrzypek, Polsko-radziecki pakt..., s. 38. 
Drugim zagadnieniem, które J. Beck zamierzał rozwiązać przy okazji toczących się rozmów, był problem Wilna. Stał na stanowisku, że prolongatę polsko-radzieckiego paktu o nieagresji winno poprzedzić wycofanie się ZSRR z popierania terytorialnych roszczeń Litwy do Wileńszczyzny. Łukasiewicz w rozmowie z Litwinowem użył mocnego argumentu stwierdzając, że utrzymanie na Litwie wrażenia, że ZSRR aprobuje politykę rządu litewskiego wobec Polski, jest sprzeczne z dążeniem do zachowania stosunków pokojowych między Polską a Związkiem Radzieckim ${ }^{101}$. Radziecki komisarz replikował, że: „nie od dzisiaj tłumaczy Litwinom, aby poszli w stosunku do Polski za przykładem sowiecko-rumuńskim. Zdaniem jego - Kowno nie może mieć złudzeń co do tego, że rząd sowiecki odnosi się bardzo krytycznie do jego dotychczasowej polityki wobec Polski. W odniesieniu do całokształtu zagadnienia stosunków polsko-litewskich, dla rządu sowieckiego jest rzeczą obojętną, czy Wileńszczyzna należy do Polski czy do Litwy jest to sprawa pomiędzy Polską a Litwą. Rządowi sowieckiemu zależy natomiast na dwóch rzeczach: na utrzymaniu stosunków pokojowych i normalnych pomiędzy Polską i Litwą i na zachowaniu niepodległości Litwy"102.

Jeszcze raz, 25 marca 1934 r., strona radziecka potwierdziła swą.gotowość do uznania każdego polsko-litewskiego porozumienia granicznego ${ }^{103}$. Natomiast kwestię globalnej synchronizacji paktów o nieagresji ZSRR ze swoimi sąsiadami, uznała za ingerencję Polski w dwustronne stosunki Związku Radzieckiego z tymi państwami. Troskę zaś Polski o bezpieczeństwo tych państw, o czym wspomniał J. Łukasiewicz, przeciwstawił B. Stomoniakow stanowisku Polski wobec deklaracji bałtyckiej, co podważało argumenty ambasadora polskiego ${ }^{104}$.

Przeciwdziałając inicjatywie polskiej, strona radziecka wystąpiła wobec państw bałtyckich z postulatem przedłużenia paktów o nieagresji na 10 lat. Odpowiedzi państw bałtyckich były prawie natychmiastowe. Państwa te ustaliły między sobą termin podpisania odpowiedniego protokółu na początek kwietnia ${ }^{105}$. W Moskwie 4 kwietnia 1934 r. nastąpiło podpisanie protokółu przedłużenia paktów o nieagresji na 10 lat, między ZSRR a przedstawicielami Łotwy, Litwy i Estonii, zaś 7 kwietnia dołączyła się do nich Finlandia ${ }^{106}$.

Według Łukasiewicza dyplomacja radziecka dążyła do odebrania stronie polskiej argumentów, które mogłyby spowodować utrudnienia w prolongacie polsko-radzieckiego paktu o nieagresji ${ }^{107}$. Wobec stanowiska strony polskiej, przekazanego 31 marca 1934 r. w rozmowie J. Łukasiewicza z B. Stomoniakowem, że nota ZSRR z 28 IX 1926 r. stwierdzająca suwerenność terytorialną Litwy (włącznie z Wileńszczyzną), określoną w artykule II radziecko-litewskiego traktatu pokojowego z 1920 r., nie odpowiada aktualnemu stanowi stosunków polsko-radzieckich, M. Litwinow záproponował podpisanie dodatkowego protokółu, w którym miało być zawarte stwierdzenie, że każda ze stron zawiadamia, że nie posiada zobowiązań sprzecznych z posta-

\footnotetext{
${ }^{101}$ Tamże.

102 Tamże.

${ }^{10.3}$ DIM, t. VI, dok. 116, s. 206.

${ }^{104}$ Tamże.

10. W. Sipols, Tajnaja diptomatija, Riga 1967, s. 214; A Skrzypek, Polsko-radziecki pakt..., s. 38.

${ }_{106}$ Tamże; zob. Protokól o przedlużeniu okresu ważności ukladu o nieagresji pomiędzy ZSRR a Łotwq z 4 NV 1934 r., DWP, t. XVII, s. 227-229; protokót ... a Litwq i protokót ... a Estoniq, tamże, s. 229-232.

${ }^{107}$ List Łukasiewicza do J. Becka z 28 III 1934 r., AAN, MSZ, Gabinet Ministra (dalej: GM), t. 33,
} k. 25 . 
nowieniami traktatu ryskiego. Litwinow zgodził się również na postulat Łukasiewicza, że sformułowanie to ma dotyczyć artykułu III traktatu ryskiego ${ }^{108}$.

Obie strony wydawały się być zadowolone. Dnia 5 V 1934 r. nastąpiło w Moskwie podpisanie protokołu o przedłużeniu polsko-radzieckiego paktu o nieagresji, a jego ratyfikacja przez Polskę nastąpiła 15 czerwca, przez ZSRR - 9 czerwca $^{109}$. Pakt ten miał obowiązywać do 31 grudnia 1945 r.

Równocześnie został podpisany protokół w sprawie wykładni art. III traktatu ryskiego, na mocy którego każda ze stron konstatowała, że: „nie ma żadnych zobowiązań i nie jest związana żadnym oświadczeniem, które byłoby sprzeczne z postanowieniami Traktatu Ryskiego"; rząd ZSRR stwierdzał też, że nota G. Cziczerina „nie może być interpretowana w ten sposób, jakby nota ta miała na celu mieszanie się Rządu Związkowego do uregulowania spraw terytorialnych wymienionych w niej" ${ }^{110}$.

Oba porozumienia zawarte między Polską a Związkiem Radzieckim zamykają serię porozumień z lat 1932-1934. Do zawarcia ich doszło już jednak w sytuacji, gdy stosunki polskoradzieckie weszły w nową fazę. Omawiany okres dla stosunków polsko-radzieckich stanowi krótki etap w historii międzywojennej obu państw.

Polska posiadająca od stycznia 1934 r. pakty o nieagresji z Niemcami i ZSRR, weszła na drogę „polityki równowagi” między Moskwą a Berlinem. Piłsudski uznawał położenie międzynarodowe Polski, determinowane paktami o nieagresji z sąsiadami, za zadowalające. Jednak według niego, stan ten nie miał trwać długo ${ }^{111}$. Stwierdzał: „Ponieważ mamy dwa pakty, siedzimy na dwóch stołkach - to nie może trwać długo. Musimy wiedzieć z którego wcześniej spadniemy i kiedy" 112 . W stosunku do Niemiec marszałek był nieufny, jednakże według niego „w razie wojny z Niemcami najprawdopodobniej nie będziemy osamotnieni, natomiast w wojnie z Rosją możemy być bardzo prawdopodobnie pozostawieni sami sobie"11.

Piłsudski był przeświadczony, że Polsce grozi większe niebezpieczeństwo ze strony Rosji niż Niemiec, rzutowało to na kierunek polityki polskiej także w następnym okresie.

${ }^{108}$ Oświadczenie J. Becka, przekazane 31 III 1934 r. przez Łukasiewicza B. Stomoniakowi, DIM, t. VI, s. 210; notatka M. Litwinowa z rozmowy z J. Łukasiewiczem z 2 IV 1934 r., tamże, s. 211; artykuł III traktatu ryskiego stwierdzał: „Rosja i Ukraina zrzekają się wszelkich praw i pretensji do ziem położonych na zachód od granicy oznaczonej w artykule II traktatu niniejszego. Ze swej strony Polska zrzeka się na rzecz Ukrainy i Białorusi wszelkich praw i pretensji do ziem położonych na wschód od tej granicy. Obie układające się strony zgadzają się, że o ile w skład ziem położonych na zachód od oznaczonej w artykule II traktatu niniejszego granicy wchodzą terytoria sporne między Polską a Litwą - sprawa przynależności tych teryroriów do jednego z tych państw należy wylącznie do Polski i Litwy", DIM, t. III, dok. 275, s. 577; Z. Gelberg, Prawo międzynarodowe i historia dyplomatyczna. Wybór dokumentów, t. II, Warszawa 1958 , s. 138.

${ }^{109}$ DIM, t. VI, dok. 126, s. 219-220.

${ }^{110}$ Tamże, dok. 127, s. 221; Komentarz redakcji, DTJS, s. 104.

${ }^{111}$ Notatka Szembeka z konferencji u Piłsudskiego w dniu 12 IV 1934 r., DTJS, dok. 62, t. I, s. 153.

112 Patrz: H. Roos, op. cit., s. 139.

${ }^{11.3}$ Komentarz redakcji do dok. 62, DTJS, t. I, s. 156. 